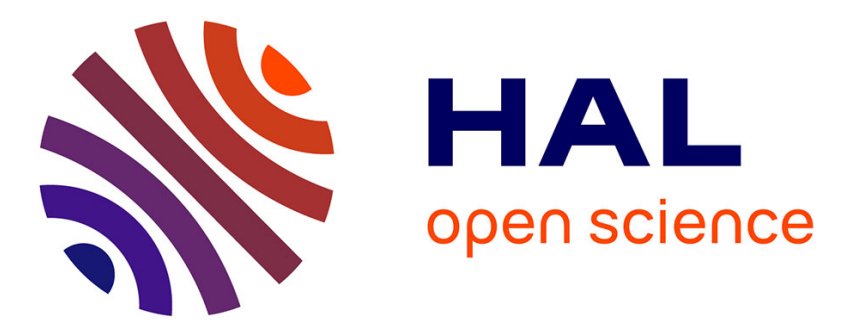

\title{
Dopamine D1 receptor-expressing neurons activity is essential for locomotor and sensitizing effects of a single injection of cocaine
}

\author{
Yukari Nakamura, Sophie Longueville, Akinori Nishi, Denis Herve, \\ Jean-antoine Girault, Yuki Nakamura
}

\section{To cite this version:}

Yukari Nakamura, Sophie Longueville, Akinori Nishi, Denis Herve, Jean-antoine Girault, et al.. Dopamine D1 receptor-expressing neurons activity is essential for locomotor and sensitizing effects of a single injection of cocaine. European Journal of Neuroscience, 2021. hal-03303492

\section{HAL Id: hal-03303492 https: / hal.sorbonne-universite.fr/hal-03303492}

Submitted on 28 Jul 2021

HAL is a multi-disciplinary open access archive for the deposit and dissemination of scientific research documents, whether they are published or not. The documents may come from teaching and research institutions in France or abroad, or from public or private research centers.
L'archive ouverte pluridisciplinaire HAL, est destinée au dépôt et à la diffusion de documents scientifiques de niveau recherche, publiés ou non, émanant des établissements d'enseignement et de recherche français ou étrangers, des laboratoires publics ou privés. 
Dopamine D1 receptor-expressing neurons activity is essential for locomotor and sensitizing effects of a single injection of cocaine

Yukari NAKAMURA ${ }^{1,2,3,4}$, Sophie LONGUEVILLE ${ }^{1,2,3}$, Akinori NISHI ${ }^{4}$, Denis HERVE ${ }^{1,2,3}$, JeanAntoine GIRAULT ${ }^{1,2,3+*}$, Yuki NAKAMURA ${ }^{1,2,3+*}$

${ }^{1}$ Inserm UMR-S 1270, 75005 Paris, France

${ }^{2}$ Sorbonne Université, Faculty of Sciences and Engineering, Paris, France

${ }^{3}$ Institut du Fer à Moulin, 75005 Paris, France

${ }^{4}$ Department of Pharmacology, Kurume University School of Medicine, 67 Asahimachi, Kurume, Fukuoka 830 - 0011, Japan

+ Equal contributions

* Co-corresponding authors.

For correspondence at the submission stage:

Jean-Antoine Girault

Institut du Fer à Moulin, Inserm \& Sorbonne University, UMR-S1270, 17, rue du Fer à Moulin, 75005 Paris, France

jean-antoine.girault@inserm.fr

Running title: Gi-DREADD in D1-neurons blocks cocaine locomotion

Number of pages: 19

Number of figures: 4

Number of words: whole manuscript, 3481, abstract, 243 


\begin{abstract}
Dopamine D1 receptors play an important role in the effects of cocaine. Here we investigated the role of neurons, which express these receptors (D1-neurons) in the acute locomotor effects of cocaine and the locomotor sensitization observed after a second injection of this drug, using the previously established two-injection protocol of sensitization. We inhibited D1-neurons using double transgenic mice conditionally expressing the inhibitory Gi-coupled designer receptor exclusively activated by designer drugs (Gi-DREADD) in D1-neurons. Chemogenetic inhibition of D1-neurons by a low dose of clozapine $(0.1 \mathrm{mg} / \mathrm{kg})$ decreased the cocaine-induced expression of Fos in striatal neurons. It diminished the basal locomotor activity and acute hyper-locomotion induced by cocaine $(20 \mathrm{mg} / \mathrm{kg})$. Clozapine $0.1 \mathrm{mg} / \mathrm{kg}$ had no effect by itself and did not alter cocaine effects in wild type mice. Inhibition of D1-neurons during the first cocaine administration prevented the sensitization of the locomotor response in response to a second cocaine administration ten days later. On day 11, inhibition of D1-neurons by clozapine stimulation of GiDREADD blocked cocaine-induced locomotion including in sensitized mice, whereas on day 12, in the absence of clozapine and D1-neurons inhibition, all mice displayed a sensitized response to cocaine. These results show that chemogenetic inhibition of D1-neurons decreases spontaneous and cocaine-induced locomotor activity. It prevents the induction and expression of sensitization in a two-injection protocol of sensitization but does not alter established sensitization. Our study further supports the central role of D1-neurons in mediating the acute locomotor effects of cocaine and its sensitization.
\end{abstract}

Keywords: sensitization, dopamine receptor, DREADD, 2-injection protocol of sensitization 


\section{$\underline{\text { Introduction }}$}

Psychostimulants such as cocaine enhance locomotor activity and repeated cocaine exposure progressively increases the locomotor responses due to sensitization processes (review in Steketee and Kalivas, 2011). Locomotor sensitization to repeated drug administration is a complex adaptation that involves several neuronal populations and is correlated with aspects of addiction including the excessive pursuit and self-administration of psychostimulant drugs (Vezina, 2004). However, multiple drug exposures can promote the parallel development of tolerance that could interfere with behavioral sensitization (Stewart and Badiani, 1993). Remarkably, a single cocaine administration induces a locomotor sensitization that increases during the first week without repetition (a property sometimes referred to as "incubation") and is long-lasting (Valjent et al., $2005,2010)$. This persistent ability of a single injection of cocaine or other drugs to increase locomotor response to a second injection several days later has been reported by several investigators (Jackson and Nutt, 1993; Lin-Chu et al., 1985; O'Neill and Sanger, 1999; Robinson et al., 1982; Vanderschuren et al., 1999, 2001; Weiss et al., 1989) and evaluated in details as the twoinjection protocol of sensitization, TIPS (Valjent et al., 2010). TIPS avoids confusing effects of repetition of the manipulations which are investigated and is a simple protocol to explore the signaling mechanisms by which drugs of abuse exert long-lasting effects (Corbillé et al., 2007; Valjent et al. 2005) as well as the role of synaptic long term potentiation in these persistent alterations (Pascoli et al. 2012). It has the advantage to allow simple manipulations during the unique initial injection and test their consequences on subsequent sensitization.

Dopamine D1 receptor (Drd1) plays a major role in the rewarding properties of drugs of abuse including cocaine (Self et al., 1996). Cocaine treatment stimulates the activity of D1-neurons in the striatum in vivo (Luo et al., 2011). SCH23390, a Drd1 antagonist, prevents locomotor sensitization (McCreary and Marsden, 1993). In Drd1 knockout mice spontaneous locomotor activity is either unchanged (Drago et al., 1996; Miner et al., 1995) or increased (Xu et al., 1994, 2000) but in most reports the locomotor response to cocaine is lost (Karlsson et al., 2008; Xu et al., 2000) as well as the ability of cocaine to induce Fos expression in striatal neurons (Drago et al., 1996; Moratalla et al., 1996). Drd1 knockout mice also show reduced sensitized locomotor responses to cocaine (Karlsson et al., 2008) and amphetamine (Karper et al., 2002). With the TIPS protocol, cocaine sensitization was absent in homozygous Drd1 knockout mice, and reduced in heterozygous mice (Valjent et al., 2010). However there is a limitation in the interpretation of knockout mice experiments, because the lack of Drd1 gene affects the expression of other genes (Xu et al., 1994) and developmental alterations cannot be excluded. Targeted mutations in mice also showed the importance in sensitization of dopamine D2 (Drd2) (Solis et al., 2021) and glutamate NMDA (Grin1) receptors (Beutler et al., 2011). These experiments provide evidence about the role of receptors but do not explore the contribution of specific neuronal populations. While local 
administration of amphetamine into the VTA is sufficient to induce Drd1-dependent locomotor sensitization (Vezina, 1996), sensitization to systemic amphetamine was prevented in mice by ablation of dorsomedial striatum D2-neurons, but not D1-neurons (Durieux et al., 2012). Metamphetamine sensitization was only delayed in mice by ablation of nucleus accumbens (NAc) shell D1-neurons (Kai et al., 2015). Cocaine locomotor sensitization was markedly decreased in mice with neurotransmission blockade (Hikida et al., 2010) or optogenetic inhibition (Chandra et al., 2013) of NAc D1-neurons. Potentiation of corticostriatal synapses onto NAc D1-neurons is a key component of locomotor sensitization in response to a single injection of cocaine (Pascoli et al., 2012). Chemogenetic inhibition of dorsal striatum nigral projection neurons also impaired amphetamine sensitization (Ferguson et al. 2011). In addition, recent work reveals that striatal cholinergic interneurons also play a role in locomotor responses to cocaine, including sensitization (Hanada et al., 2018; Lewis et al., 2020). Thus, available evidence indicates that locomotor sensitization can be triggered by just a single exposure to psychostimulants and involves several neuronal populations in the striatum.

In the current study we addressed the global role of D1-neurons asking two simple questions: Does inhibition of D1-neurons alter i) the acute locomotor response to cocaine and ii) the induction or expression of sensitization in the TIPS protocol? To address these questions we used chemogenetics with designer receptor exclusively activated by designer drug (DREADDs, Roth BL et al., 2016) and expressed hM4Di, an inhibitory DREADD, referred to below as Gi-DREADD, selectively in Drd1-expressing cells. Since recent work showed that DREADD stimulation with low doses of clozapine (CLZ) is faster and at least as efficient as clozapine-N-oxide (CNO), the commonly used ligand (Gomez et al., 2017), an observation confirmed in our laboratory (Nakamura et al., 2020), we used CLZ to activate hM4Di and inhibit D1-neurons.

\section{Materials and Methods}

\section{Animals and treatments}

We used heterozygous bacterial artificial chromosome (BAC) Drd1-Cre transgenic (Drd1-Cre) mice expressing Cre recombinase under the control of the dopamine D1 receptor gene (Drd1) promoter (GENSAT project, EY262 line), bred onto a C57BL/6J genetic background. Gi-DREADD (B6N.129-

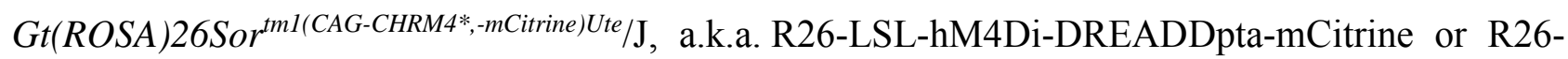
hM4Di/mCitrine) mice were purchased from the Jackson Laboratory (stock \#026219). We crossed Drd1-Cre mice with Gi-DREADD mice. A subset of their offspring carried both Drd1-Cre and R26$\mathrm{hM} 4 \mathrm{Di} / \mathrm{mCitrine}$ alleles, allowing effective removal of the stop cassette and expression of GiDREADD (mice referred to as D1-Gi-DREADD below, Fig. 1A). Males and females, 10-21-weekold at the beginning of the experiments, were used. Genotypes were determined by polymerase chain reaction (PCR) on mouse tail DNA samples. Cocaine-HCl (Sigma, France) was dissolved in $9 \mathrm{~g} \mathrm{~L}^{-1}$ $\mathrm{NaCl}$ solution (saline). CLZ (Sigma-Aldrich) was first dissolved in DMSO, and then diluted in saline 
(final DMSO concentration, $\left.0.1 \mathrm{~mL} \mathrm{~L}^{-1}\right)$. Cocaine $\left(20 \mathrm{mg} \mathrm{kg}{ }^{-1}\right)$ and CLZ $\left(0.1 \mathrm{mg} \mathrm{kg}^{-1}\right)$ were administered by intraperitoneal injection in a volume of $10 \mathrm{~mL} \mathrm{~kg}^{-1}$ body weight. The dose of CLZ was chosen to be efficient for Gi-DREADD stimulation but without other identified pharmacological effects, according to previous reports (Gomez et al., 2017; Nakamura et al., 2020). Mice were housed under a 12-hour light/12-hour dark cycle with free access to food and water. All animal procedures were approved by the Ministère de l'Education Nationale de l'Enseignement Supérieur de la Recherche (France, project APAFIS\#8196-201704201224850 v1. All methods in this study were performed in accordance with the relevant guidelines and regulations.

\section{Behavioral analysis}

Locomotor activity was measured in a circular corridor with four infrared beams placed at every $90^{\circ}$ angles (Imetronic, Pessac, France) in a low luminosity environment (locomotor activity box, LAbox). Counts were incremented by consecutive interruptions of two adjacent beams. Locomotor sensitization induced by a single cocaine injection was studied as in Valjent et al. (2010), as descibed in Fig. 1B-C. Mice were habituated to handling, test apparatus, and procedures for 3 consecutive days (Days -3 to -1 ). In this habituation period, mice received every day a first saline injection and were placed in the LA-box (T0 min). Thirty minutes later, they received a second saline injection (T30 min) and were put back in the LA-box for $1 \mathrm{~h}$. On experimental days (Day 0, Days 10-12), mice were handled in the same manner, except that they were injected with the solutions indicated in Fig. 1B at $\mathrm{T} 0 \mathrm{~min}$ and $\mathrm{T} 30 \mathrm{~min}$, respectively.

\section{Tissue preparation and immunofluorescence}

For the experiment in which the brains were used for immunohistofluorescence, D1-Gi-DREADD mice different from those used for sensitization experiments were treated as above on Day 0 but killed 90 min after cocaine injection (Fig. 2A) with a lethal dose of pentobarbital (500 mg kg-1, i.p., SanofiAventis, France) and perfused transcardially with $40 \mathrm{~g} \mathrm{~L}^{-1}$ paraformaldehyde in $0.1 \mathrm{M}$ sodium phosphate buffer (Fig. 2A). Brains were post-fixed overnight at $4^{\circ} \mathrm{C}$, cut into free-floating sections $(30 \mu \mathrm{m})$ with a vibrating microtome (Leica) and kept at $-20^{\circ} \mathrm{C}$ in a solution containing $300 \mathrm{~mL} \mathrm{~L}^{-1}$ ethylene glycol, $300 \mathrm{~mL} \mathrm{~L}^{-1}$ glycerol in $0.1 \mathrm{M}$ sodium phosphate buffer. Immunolabeling procedures were as previously described (Valjent et al., 2000). Primary antibodies were rabbit Fos antibodies (1:1000, Santa Cruz, \#sc-52) and mouse hemagglutinin (HA) antibodies (1:50, Sigma, \#A-2095). Secondary antibodies were anti-rabbit A488-labeled antibody (1:400, Invitrogen, \#A-21206) and anti-mouse A555-labeled antibody (1:400; Invitrogen, \#A-31570). Images were acquired using a Leica SP5-II confocal microscope at the Institut du Fer à Moulin Tissue and Cell Imaging Facility.

\section{Statistical analysis}

When normal distribution was not rejected by d'Agostino-Pearson and Shapiro-Wilk tests, data were analyzed with Student's $t$ test or paired t-test or two-way ANOVA followed by post hoc comparisons 
as indicated in the figure legends. When normal distribution was rejected, analysis was done with non-parametric tests. All statistical analyses were performed using Prism version 6.00 for Windows (GraphPad Software, La Jolla, CA, USA). A threshold value for significance of $p<0.05$ was used throughout the study.

\section{$\underline{\text { Results }}$}

D1-Gi-DREADD stimulation prevents cocaine-induced hyperlocomotion and Fos expression in the striatum

We first assessed the functionality of Gi-DREADD by testing the ability of CLZ to alter cocaineinduced locomotion and prevent cocaine-induced expression of Fos, a marker of activated neurons. D1-Gi-DREADD mice were treated with CLZ $(0.1 \mathrm{mg} / \mathrm{kg})$ or vehicle and $30 \mathrm{~min}$ later with cocaine (Fig. 2A). Cocaine markedly increased locomotion in the group of vehicle-pretreated mice whereas CLZ-pretreated mice displayed little locomotor activity (Fig. 2B). Brains were collected 90 min after cocaine injection and we quantified the percentage of cells expressing Gi-DREADD, revealed by HA immunoreactivity, a peptide tag of Gi-DREADD, which were also positive for Fos (Fig. 2C). We analyzed this percentage in the dorsolateral and dorsomedial striatum and in the NAc core and shell regions (Fig. 2D). In both vehicle- and cocaine-treated mice, most Fos-positive cells, but not all, coexpressed HA (and thus Gi-DREADD), indicating that Fos was mainly induced in D1-neurons as previously reported (Bertran-Gonzalez et al., 2008; Guez-Barber et al., 2011; Zhang et al., 2006). As compared with vehicle, CLZ pretreatment decreased Fos-positive/HA-positive ratio in the NAc shell, dorsomedial, and dorsolateral striatum (Fig. 2E). These results indicated that stimulating GiDREADD with CLZ inhibited the cocaine-induced response of striatal D1-neurons.

\section{Inhibition of D1-neurons decreases basal and cocaine-induced locomotor activity}

Next, using different groups of mice, we analyzed how inhibition of D1-neurons affected spontaneous locomotion and locomotor responses after the first and second cocaine injection (see Fig. 1B-C). On Day 0, during the 30-min period after CLZ pretreatment (groups 3-4) the basal locomotor activity of mice was decreased as compared with vehicle-pretreated mice (groups 1-2, Fig. 3A-B). In contrast CLZ pretreatment had no effect in wild type mice (WT, Fig. 3B, groups 5-8). During the 60 min after cocaine injection, locomotor activity was dramatically decreased in CLZ-pretreated D1-GiDREADD mice (group 4) as compared to vehicle-pretreated mice (group 2, Fig. 3A, C), whereas CLZ injection did not alter cocaine-induced hyper-locomotion in WT mice (Fig. 3C, group 8). Thus, inhibition of Gi-DREADD-expressing D1-neurons by CLZ decreased the spontaneous locomotor activity and cocaine-induced hyper-locomotion. Although sex-dependent differences in the response to cocaine have been reported (Festa et al. 2006, Rivera et al. 2021, Kokane and Perrotti, 2020), the sex of the mice, which was evenly distributed in all groups of mice used in these experiments, did not modify the responses (Figs. 1B, 3D). 


\section{Inhibition of D1-neurons impairs the induction of cocaine locomotor sensitization}

We then investigated the effects of chemogenetic inhibition of D1-neurons during the first injection of cocaine on locomotor sensitization. To test this effect we used the TIPS protocol which avoids confusing effects due to repeated drugs administration, and provides a robust assessment of sensitization (Valjent et al., 2010). On Day 10, we injected cocaine to all D1-Gi-DREADD mice (Fig. 3E). All groups displayed an increased locomotor activity after cocaine injection (Fig. $3 \mathbf{E})$. In the groups that had not received CLZ on Day 0 (groups 1-2), locomotor response to cocaine on Day10 was significantly increased in the mice injected with cocaine for the second time (group 2) as compared to those that had previously received saline (group 1, Fig. 3E-F). This result confirmed the locomotor sensitization induced in the TIPS protocol. In contrast, in the mice pretreated with CLZ on Day 0 (groups 3-4), the responses to cocaine were not significantly different whether or not they had received cocaine a week before. Thus sensitization was blunted in group 4 mice that had received cocaine on Day 0 in the presence of CLZ (Fig. 3E-F). In WT mice (groups 5-8) the locomotor response to the second injection of cocaine was increased (groups 6, 8) as compared to mice previously injected with saline (groups 5,7), whether they also had received on Day 0 CLZ (group 8) or vehicle (group 6, Fig. 3F).

\section{Inhibition of D1-neurons blocks previously sensitized cocaine-induced locomotion}

To assess the acute effects of D1-neuron inhibition on locomotor activity in mice previously exposed to cocaine, we injected on Day 11 the same mice as in Fig. 3 with CLZ, followed 30 min later by cocaine (Fig. 4A). In the four D1-Gi-DREADD groups (1-4), the locomotor responses (30-90 min) were lower than those observed the day before in the absence of CLZ (Day 10, compare Fig. 3 E-F and Fig. 4A-B) and there was no significant difference between groups on Day 11 (Fig. 4B). In contrast, in all groups of WT mice injected with CLZ (groups 5-8), cocaine induced a clear hyperlocomotion (Fig. 4B), ruling out a non-specific pharmacological effect of CLZ. Paired analysis showed that locomotor responses to cocaine on Day 11 were significantly decreased compared with those on Day10 in the four D1-Gi-DREADD groups (Fig. 4C), including group 2 which was clearly sensitized on Day 10 (Fig. 3D-E). These results showed that inhibition of D1-neurons strongly decreased the cocaine-induced hyper-locomotion, including in mice with already established cocainesensitized locomotion (group 2).

\section{Inhibition of D1-neurons on Day 11 does not alter established cocaine sensitization on Day 12} Because cocaine TIPS is protein synthesis- and context-dependent (Valjent et al., 2010) and context memory retrieval in the presence of a protein synthesis inhibitor can disrupt locomotor sensitization in rats (Bernardi et al., 2007), we asked whether exposure of mice to the LA-box and cocaine in the presence of CLZ could have persistent effects on cocaine locomotor responses. We tested whether D1-neuron inhibition on Day 11 by CLZ in D1-Gi-DREADD mice affected the locomotor response to cocaine the next day (Day 12). On Day 12, all groups were injected with vehicle and 30 min later 
with cocaine. There was no significant difference in locomotor activity (30-90 $\mathrm{min}$ ) between the 4 D1-Gi-DREADD groups (Fig. 4D, E). These results were similar to those observed in WT mice receiving the same treatment on Day 12 (groups 5-8, Fig. 4E). Paired analysis showed that the locomotor response to cocaine (30-90 min) on Day 12 was significantly increased in Groups 1, 3, and 4, as compared to Day 10 (Fig. 4F), indicating the existence of a sensitization step. No significant difference between Day 10 and 12 was observed in group 2 (Fig. 4F), suggesting that sensitization had reached a plateau in this group, in agreement with previous report showing that cocaine sensitization to the $2^{\text {nd }}$ cocaine injection is time-dependent and becomes maximum about 7 days after the first cocaine injection (Valjent et al., 2010). None of the groups displayed any decreased cocaineinduced locomotor activity on Day 12 as compared to Day 10, showing that inhibition of D1-neurons during cocaine exposure in paired context on Day 11 did not diminish previously established sensitization.

\section{Discussion}

In this study, we used double transgenic mice with conditional expression of Gi-DREADD in neurons that express Drd1 and showed that inhibition of these neurons decreased spontaneous locomotor activity and acute cocaine-induced hyper-locomotion. Inhibition of D1-neurons during the first cocaine administration blunted sensitization to a cocaine challenge ten days later. In addition, acute inhibition of D1-neurons prevented cocaine-induced locomotor activity in previously sensitized mice. However, inhibition of D1-neurons concomitant with cocaine injection in the drug-associated environment did not diminish previously acquired sensitization.

For pharmacological activation of Gi-DREADD, we used low doses of CLZ instead of commonly used CNO. CNO induces cellular DREADD-mediated effects with different time-courses in the brain and peripheral organs (Alexander et al., 2009). The effects of systemic administration of CNO on DREADD-expressing neurons appear to result mainly from the action of CLZ produced by its metabolic degradation, which crosses the blood brain barrier more efficiently and has a higher affinity for DREADDs (Gomez et al., 2017). In a recent fMRI study of DREADD-induced activation of D1-neurons, we confirmed a more rapid and efficient effect of low doses of CLZ as compared to CNO (Nakamura et al., 2020). Here low doses of CLZ (0.1 mg/kg, i.p.) had clear effects only in mutant mice expressing Gi-DREADD. Although CLZ has numerous endogenous targets at higher doses including serotonin, dopamine, and muscarinic acetylcholine receptors (Bonaventura et al., 2019; Schotte et al., 1993), in our experiments we did not observe any effect of the low dose of CLZ used in WT mice, ruling out off-target effects.

Cell-type-specific technologies allow better characterization of cell populations involved in the effects of psychostimulants (Durieux et al., 2011; Yager et al., 2015). Optogenetic inhibition of striatal D1- but not D2-neurons inhibited the expression of cocaine-induced locomotor sensitization, (Lee et al., 2017). Repeated association of optogenetic inhibition of NAc D1-neurons with cocaine 
injection decreased sensitization (Chandra et al. 2013). Chemogenetic inhibition of dorsal striatum dynorphin-neurons (corresponding to D1) but not enkephalin-neurons (D2) impaired behavioral sensitization although it did not alter spontaneous activity or acute response to amphetamine (Ferguson et al., 2011). In our study, we observed a strong effect of inhibiting D1-neurons on spontaneous locomotor activity and acute response to cocaine. These stronger effects may result from the wider inhibition of D1-neurons excitability throughout the brain, including in dorsal striatum, NAc and cerebral cortex, in contrast to the restricted inhibition in the dorsomedial striatum in the study of Ferguson et al. In addition, it is possible that the efficacy of CLZ to activate DREADD is higher and more rapid than that of CNO, as suggested by Gomez et al. (2017).

Decreasing activity of the medial prefrontal cortex afferent to the NAc did not impair amphetamine sensitization (Kerstetter et al., 2016). In contrast, increasing activity of striatopallidal neurons (D2-neurons) with Gs-DREADD prevented amphetamine sensitization (Farrell et al., 2013). This is in agreement with the results on mice lacking Drd2, a receptor exerting an inhibitory effect on D2-neurons, in which acute response to cocaine or to a Drd1 agonist (SKF81297) was blunted and locomotor sensitization to cocaine and amphetamine attenuated (Solis et al. 2021). Combined with our current findings, these reports underline the importance of the balance between D1- and D2-neurons in regulating sensitization.

Although Drd1 is predominantly expressed in a subset of striatal projection neurons (Gerfen et al., 1990), it is also found at lower levels in some neurons of other regions such as prefrontal cortex (Santana et al. 2009) and hippocampus (Gangarossa et al., 2012) and some nonneuronal cells in and outside the brain (Amenta et al., 1997, Corkrum et al., 2020). These cells were potentially expressing Gi-DREADD and could have responded to CLZ stimulation, but not necessarily by an inhibition, as suggested for hippocampal astrocytes (Nam et al. 2019). We therefore cannot formally exclude that the effects of CLZ were also involving cells outside the striatum.

Drug addiction is a complex disorder in which pathological memories play a critical role in the maintenance of addictive behaviors and relapse to drug seeking (reviews in Hyman et al., 2006; Robbins et al., 2008; Tronson and Taylor, 2013). Several rodent studies aimed to erase or weaken these drug-associated memories by inducing targeted disruption of memory reconsolidation processes. Memory reconsolidation is the process by which memories become labile under certain conditions of reactivation (retrieval) before being stabilized again and persistently stored in the brain (review in Lee et al., 2017). Drug-induced conditioned place preference was attenuated or erased by combining re-exposure to the drug-paired stimuli and/or the drug itself with inhibition of protein synthesis (Valjent et al., 2006; Dunbar and Taylor., 2016), ERK signaling (Valjent et al., 2006), D1 receptors (Yan et al., 2014, Marion-Poll et al., 2019) or knockdown of the immediate early gene zif268/Egr1 (Lee et al., 2005, 2006; Théberge et al., 2010). Locomotor sensitization may undergo protein synthesis-dependent reconsolidation when the animals are briefly exposed to the 
drug-associated context without drug (Bernardi et al. 2007). Locomotor sensitization induced by a single injection of cocaine was shown to involve potentiation of excitatory synapses onto nucleus accumbens D1-neurons and was erased by optogenetic depotentiation of cortical inputs to these neurons (Pascoli et al., 2012). Complete DREADD-induced inhibition of D1 neurons in the current study did not erase sensitization however, presumably because it did not modify synaptic input weights.

In conclusion, our results show that specific inhibition of D1-neurons strongly decreases spontaneous and cocaine-induced locomotor activity and alters locomotor sensitization induced by a single injection of cocaine. Our study suggests that selective manipulation of the excitability of these neurons is an interesting therapeutic approach in the context of addiction. 


\section{Acknowledgments}

Research in the laboratory of JAG was supported by Inserm and Sorbonne University and by grants from Fondation pour la Recherche Médicale (FRM DPA20140629798 and EQU201903007844) and ANR (Epitraces, ANR-16-CE16-0018). Equipment at the IFM was funded in part by Fondation pour la recherche sur le cerveau (FRC) and Rotary Espoir en Tête, and by DIM Cerveau et Pensée Région Ile-de-France. YN was recipient of an Uehara Memorial Foundation fellowship and a Fyssen Foundation fellowship. Cell imaging was done at the Institut du Fer à Moulin Tissue and Cell Imaging Facility and mice were bred and studied at the Institut du Fer à Moulin Rodent Breeding and Phenotyping Facility.

\section{Competing Interests}

The authors declare no competing interest.

\section{Authors contributions}

Yukari N carried out experiments, analyzed results and wrote the manuscript, SL and Yuki N carried out experiments and analyzed results, AN analyzed results, JAG supervised the work, DH, JAG, and Yuki N planned and conceived experiments, analyzed results and wrote the manuscript.

\section{Data accessibility}

Original data are accessible upon request

\section{Abbreviations}

CLZ: clozapine

CNO: clozapine-N-oxide

D1-neurons: dopamine D1 receptor-expressing neurons

Drd1: dopamine D1 receptor

Drd1-Cre mice: Drd1-Cre transgenic mice

DREADD: designer receptor exclusively activated by designer drugs

NAc: nucleus accumbens

TIPS: two-injection protocol of sensitization 


\section{References}

Alexander, G.M., Rogan, S.C., Abbas, A.I., Armbruster, B.N., Pei, Y., Allen, J.A., Nonneman, R.J., Hartmann, J., Moy, S.S., Nicolelis, M.A., McNamara, J.O., \& Roth, B.L. (2009) Remote control of neuronal activity in transgenic mice expressing evolved G protein-coupled receptors. Neuron, 63, 27 39.

Amenta, F. (1997) Light microscope autoradiography of peripheral dopamine receptor subtypes. Clin. Exp. Hypertens, 19, 27-41.

Bernardi, R.E., Matthew, K.M. \& Berger, S.P. (2007) Anisomycin disrupts a contextual memory following reactivation in a cocaine-induced locomotor activity paradigm. Behav Neurosci, 121, 156-163.

Bertran-Gonzalez, J., Bosch, C., Maroteaux, M., Matamales, M., Hervé, D., Valjent, E., \& Girault, J.A. (2008) Opposing patterns of signaling activation in dopamine D1 and D2 receptor-expressing striatal neurons in response to cocaine and haloperidol. J Neurosci, 28, 5671-5685.

Beutler, L.R., Wanat, M.J., Quintana, A., Sanz, E., Bamford, N.S., Zweifel, L.S., \& Palmiter, R.D. (2011) Balanced NMDA receptor activity in dopamine D1 receptor (D1R)- and D2R-expressing medium spiny neurons is required for amphetamine sensitization. Proc Natl Acad Sci USA., 108, 4206-4211.

Bonaventura, J., Eldridge, M.A.G., Hu, F., Gomez, J.L., Sanchez-Soto, M., Abramyan, A.M., Lam, S., Boehm, M.A., Ruiz, C., Farrell, M.R., Moreno, A., Galal Faress, I.M., Andersen, N., Lin, J.Y., Moaddel, R., Morris, P.J., Shi, L., Sibley, D.R., Mahler, S. V., Nabavi, S., Pomper, M.G., Bonci, A., Horti, A.G., Richmond, B.J., \& Michaelides, M. (2019) High-potency ligands for DREADD imaging and activation in rodents and monkeys. Nat Commun, 10, 4627.

Chandra, R., Lenz, J., Gancarz, A.M., Chaudhury, D., Schroeder, G.L., Han, M.H., Cheer, J.F., Dietz, D.M., \& Kay Lobo, M. (2013) Optogenetic inhibition of D1R containing nucleus accumbens neurons alters cocaine-mediated regulation of Tiam1. Front Mol Neurosci, 6, 1-8.

Corbillé, A.G., Valjent, E., Marsicano, G., Ledent, C., Lutz, B., Hervé, D., Girault, J.A., (2007) Role of Cannabinoid Type 1 Receptors in Locomotor Activity and Striatal Signaling in Response to Psychostimulants. J. Neurosci., 27, 6937-47.

Corkrum, M., Covelo, A., Lines, J., Bellocchio, L., Pisansky, M., Loke, K., Quintana, R., Rothwell, P.E., Lujan, ., Marsicano, G., Martin, E.D., Thomas, M.J., Kofuji, P., \& Araque, A. (2020) Dopamine-evoked synaptic regulation in the nucleus accumbens requires astrocyte activity. Neuron, 105, 1036-1047.e5.

Drago, J., Gerfen, C.R., Westphal, H., \& Steiner, H. (1996) D1 dopamine receptor-deficient mouse: cocaine-induced regulation of immediate-early gene and substance $\mathrm{P}$ expression in the striatum. Neuroscience, 74, 813-823.

Dunbar, A.B., \& Taylor J.R. (2016) Inhibition of protein synthesis but not $\beta$-adrenergic receptors blocks reconsolidation of a cocaine-associated cue memory. Learn Mem, 23, 391-398.

Durieux, P.F., Schiffmann, S.N. \& de Kerchove d'Exaerde, A. (2011) Targeting neuronal populations of the striatum. Front Neuroanat, 5, 1-9. 
Durieux, P.F., Schiffmann, S.N., \& De Kerchove D'Exaerde, A. (2012) Differential regulation of motor control and response to dopaminergic drugs by D1R and D2R neurons in distinct dorsal striatum subregions. EMBO J, 31, 640-653.

Farrell, M.S., Pei, Y., Wan, Y., Yadav, P.N., Daigle, T.L., Urban, D.J., Lee, H.M., Sciaky, N., Simmons, A., Nonneman, R.J., Huang, X.P., Hufeisen, S.J., Guettier, J.M., Moy, S.S., Wess, J., Caron, M.G., Calakos, N., \& Roth, B.L. (2013) A Gas DREADD mouse for selective modulation of cAMP production in striatopallidal neurons. Neuropsychopharmacology,. 38, 854-862.

Festa, E.D., Jenab, S., Weiner, J., Nazarian, A., Niyomchai, T., Russo, S.J., Kemen, L.M., Akhavan, A., Wu, H.B.K., \& Quinones-Jenab, V. (2006) Cocaine-induced sex differences in D1 receptor activation and binding levels after acute cocaine administration. Brain Res. Bull., 68, 277-284.

Ferguson, S.M., Eskenazi, D., Ishikawa, M., Wanat, M.J., Phillips, P.E.M., Dong, Y., Roth, B.L., \& Neumaier, J.F. (2011) Transient neuronal inhibition reveals opposing roles of indirect and direct pathways in sensitization. Nat Neurosci, 14, 22-24.

Gangarossa, G., Longueville, S., De Bundel, D., Perroy, J., Hervé, D., Girault, J.A., \& Valjent, E. (2012) Characterization of dopamine D1 and D2 receptor-expressing neurons in the mouse hippocampus.Hippocampus, 22, 2199-2207.

Gerfen, C.R., Engber, T.M., Mahan, L.C., Susel, Z., Chase, T.N., Monsma, F.J., \& Sibley, D.R. (1990) D1 and D2 dopamine receptor-regulated gene expression of striatonigral and striatopallidal neurons. Science, 250, 1429-1432.

Gomez, J.L., Bonaventura, J., Lesniak, W., Mathews, W.B., Sysa-Shah, P., Rodriguez, L.A., Ellis, R.J., Richie, C.T., Harvey, B.K., Dannals, R.F., Pomper, M.G., Bonci, A., \& Michaelides, M. (2017) Chemogenetics revealed: DREADD occupancy and activation via converted clozapine. Science, 357, 503-507.

Guan, L.C., Robinson, T.E., Becker, J.B. (1985) Sensitization of rotational behavior produced by a single exposure to cocaine. Pharmacol. Biochem. Behav., 22, 901-903.

Guez-Barber, D., Fanous, S., Golden, S.A., Schrama, R., Koya, E., Stern, A.L., Bossert, J.M., Harvey, B.K., Picciotto, M.R., \& Hope, B.T. (2011) FACS identifies unique cocaine-induced gene regulation in selectively activated adult striatal neurons. J Neurosci, 31, 4251-4259.Hanada, Y., Kawahara, Y., Ohnishi, Y.N., Shuto, T., Kuroiwa, M., Sotogaku, N., Greengard, P., Sagi, Y., \& Nishi, A. (2018) P11 in cholinergic interneurons of the nucleus accumbens is essential for dopamine responses to rewarding stimuli. eNeuro, 5, 1-21.

Hanada, Y., Kawahara, Y., Ohnishi, Y.N., Shuto, T., Kuroiwa, M., Sotogaku, N., Greengard, P., Sagi, Y., \& Nishi, A. (2018) P11 in cholinergic interneurons of the nucleus accumbens is essential for dopamine responses to rewarding stimuli. eNeuro, 5, 1-21. 
Hikida, T., Kimura, K., Wada, N., Funabiki, K., \& Nakanishi Shigetada, S. (2010) Distinct roles of synaptic transmission in direct and indirect striatal pathways to reward and aversive behavior. Neuron, 66, 896-907.

Jackson, H.C. \& Nutt, D.J. (1993) A single preexposure produces sensitization to the locomotor effects of cocaine in mice. Pharmacol Biochem Behav, 45, 733-735.

Kai, N., Nishizawa, K., Tsutsui, Y., Ueda, S., \& Kobayashi, K. (2015) Differential roles of dopamine D1 and D2 receptor-containing neurons of the nucleus accumbens shell in behavioral sensitization. J Neurochem, 135, 1232-1241.

Karlsson, R.M., Hefner, K.R., Sibley, D.R., \& Holmes, A. (2008) Comparison of dopamine D1 and D5 receptor mice for cocaine locomotor sensitization. Psychopharmacology (Berl), 200, 117-127.

Karper, P. E., De La Rosa, H., Newman, E.R., Krall, C.M., Nazarian, A., McDougall, S.A., \& Crawford, C.A. (2002) Role of D1-like receptors in amphetamine-induced behavioral sensitization: a study using D1A receptor knockout mice. Psychopharmacology, 159, 407-414.

Kerstetter, K.A., Wunsch, A.M., Nakata, K.G., Donckels, E., Neumaier, J.F., \& Ferguson, S.M. (2016) Corticostriatal afferents modulate responsiveness to psychostimulant drugs and drugassociated stimuli. Neuropsychopharmacology. 41, 1128-1137.

Kokane, S.S. \& Perrotti, L.I. (2020) Sex differences and the role of estradiol in mesolimbic reward circuits and vulnerability to cocaine and opiate addiction. Front. Behav. Neurosci., 14, 1-21.

Lee, J.L.C., Di Ciano, P., Thomas, K.L., \& Everitt, B.J. (2005) Disrupting reconsolidation of drug memories reduces cocaine-seeking behavior. Neuron, 47, 795-801.

Lee, J.L., Milton, A.L. \& Everitt, B.J. (2006) Cue-induced cocaine seeking and relapse are reduced by disruption of drug memory reconsolidation. J Neurosci, 26, 5881-5887.

Lee, J.L., Nader, K. \& Schiller D. (2017) An update on memory reconsolidation updating. Trends Cogn Sci, 21, 531-545.

Lee, D., Creed, M., Jung, K., Stefanelli, T., Wendler, D.J., Oh, W.C., Mignocchi, N.L., Lüscher, C., \& Kwon, H.B. (2017) Temporally precise labeling and control of neuromodulatory circuits in the mammalian brain. Nat Methods, 14, 495-503.

Lewis, R.G., Serra, M., Radl, D., Gori, M., Tran, C., Michalak, S.E., Vanderwal, C.D., \& Borrelli, E. (2020) Dopaminergic control of striatal cholinergic interneurons underlies cocaine-induced psychostimulation. Cell Rep, 31, 107527.

Lin-Chu, G., Robinson, T.E., \& Becker, J.B. (1985) Sensitization of rotational behavior produced by a single exposure to cocaine. Pharmacol. Biochem. Behav., 22, 901-903.

Luo, Z., Volkow, N.D., Heintz, N., Pan, Y., \& Du, C. (2011) Acute cocaine induces fast activation of D1 receptor and progressive deactivation of D2 receptor striatal neurons: in vivo optical microprobe $\left[\mathrm{Ca}^{2+}\right] \mathrm{i}$ imaging. J Neurosci, 31, 13180-1390.

Marion-Poll, L., Besnard, A., Longueville, S., Valjent, E., Engmann, O., Caboche, J., Hervé, D., \& Girault, J.A. (2019) Cocaine conditioned place preference: unexpected suppression of preference due to testing combined with strong conditioning. Addict Biol, 24, 364-375. 
McCreary, A.C. \& Marsden, C.A., (1993) Cocaine-induced behaviour: dopamine D1 receptor antagonism by SCH 23390 prevents expression of conditioned sensitisation following repeated administration of cocaine. Neuropharmacology, 32, 387-391.

Miner, L.L., Drago, J., Chamberlain, P.M., Donovan, D., \& Uhl, G.R. (1995) Retained cocaine conditioned place preference in D1 receptor deficient mice. Neuroreport, 6, 2314-2316.

Moratalla, R., Xu, M., Tonegawa, S., \& Graybiel, A.M. (1996) Cellular responses to psychomotor stimulant and neuroleptic drugs are abnormal in mice lacking the D1 dopamine receptor. Proc. Natl. Acad. Sci. U. S. A., 93, 14928-14933

Nakamura, Y., Nakamura, Y., Pelosi, A., Djemai, B., Debacker, C., Hervé, D., Girault, J.A., \& Tsurugizawa, T. (2020) fMRI detects bilateral brain network activation following unilateral chemogenetic activation of direct striatal projection neurons. Neuroimage. 220, 117079.

Nam, M.H., Han, K.S., Lee, J., Won, W., Koh, W., Bae, J.Y., Woo, J., Kim, J., Kwong, E., Choi, T.Y., Chun, H., Lee, S.E., Kim, S.B., Park, K.D., Choi, S.Y., Bae, Y.C., \& Lee, C.J. (2019) Activation of astrocytic $\mu$-opioid receptor causes conditioned place preference. Cell Rep., 28, 1154-1166.e5.

O’Neill, M.F., Sanger, G.J (1999) A single pretreatment with MK-801 or cocaine enhances their locomotor stimulant effects in rats. Brain Res., 834, 103-111

Pascoli, V., Turiault, M., \& Lüscher, C. (2012) Reversal of cocaine-evoked synaptic potentiation resets drug-induced adaptive behaviour. Nature, 481, 71-76.

Paxinos, G. \& Franklin, K.B.J. (2001) The mouse brain in stereotaxic coordinates. 2nd Edition, Academic Press, San Diego.

Rivera, P., Aranda, J., Alén, F., Vargas, A., Serrano, A., Pavón, F.J., Orio, L., Rubio, L., Moratalla, R., de Fonseca, F.R., \& Suárez, J. (2021) Sex-specific behavioral and neurogenic responses to cocaine in mice lacking and blocking dopamine D1 or dopamine D2 receptors. J. Comp. Neurol., 529, 1724-1742.

Robbins, T.W., Ersche, K.D. \& Everitt, B.J. (2008) Drug addiction and the memory systems of the brain. Ann N Y Acad Sci, 1141, 1-21.

Robinson, T.E., Becker, J.B., \& Presty, S.K. (1982) Long-term facilitation of amphetamine-induced rotational behavior and striatal dopamine release produced by a single exposure to amphetamine: sex differences. Brain Res., 253, 231-241.

Roth, B.L. (2016) DREADDs for Neuroscientists. Neuron, 89, 683-694.

Santana, N., Mengod, G., \& Artigas, F. (2009) Quantitative analysis of the expression of dopamine D1 and D2 receptors in pyramidal and GABAergic neurons of the rat prefrontal cortex.

Cereb. Cortex, 19, 849-860.

Schotte, A., Janssen, P.F.M., Megens, A.A.H.P., \& Leysen, J.E. (1993) Occupancy of central neurotransmitter receptors by risperidone, clozapine and haloperidol, measured ex vivo by quantitative autoradiography. Brain Res., 631, 191-202.

Self, D.W., Barnhart, W.J., Lehman, D.A., \& Nestler, E.J. (1996) Opposite modulation of cocaine- 
seeking behavior by D1 - and D2-like dopamine receptor Agonists. Science, 271, 1586-1589. Solís, O., García-Sanz, P., Martín, A.B., Granado, N., Sanz-Magro, A., Podlesniy, P., Trullas, R., Murer, M.G., Maldonado, R., \& Moratalla, R. (2021) Behavioral sensitization and cellular responses to psychostimulants are reduced in D2R knockout mice. Addict. Biol., 26, 1-11.

Steketee, J.D. \& Kalivas, P.W. (2011) Drug wanting: behavioral sensitization and relapse to drug-seeking behavior. Pharmacol Rev, 63, 348-365.

Stewart, J. \& Badiani, A. (1993) Tolerance and sensitization to the behavioral effects of drugs. Behav Pharmacol, 4, 289-312.

Théberge, F.R.M., Milton, A.L., Belin, D., Lee, J.L.C., \& Everitt, B.J. (2010) The basolateral amygdala and nucleus accumbens core mediate dissociable aspects of drug memory reconsolidation. Learn Mem, 17, 444-453.

Tronson, N.C. \& Taylor, J.R. (2013) Addiction: a drug-induced disorder of memory reconsolidation. Curr Opin Neurobiol, 23, 573-580.

Valjent, E., Corvol, J.C., Pages, C., Besson, M.J., Maldonado, R., \& Caboche, J. (2000) Involvement of the extracellular signal-regulated kinase cascade for cocaine-rewarding properties. J Neurosci, 20, 87018709.

Valjent, E., Pascoli, V., Svenningsson, P., Paul, S., Enslen, H., Corvol, J.C., Stipanovich, A., Caboche, J., Lombroso, P.J., Nairn, A.C., Greengard, P., Hervé, D., \& Girault, J.A. (2005) Regulation of a protein phosphatase cascade allows convergent dopamine and glutamate signals to activate ERK in the striatum. Proc. Natl. Acad. Sci. U. S. A., 102, 491-496.

Valjent, E., Corbillé, A.G., Bertran-Gonsalez, J., Hervé, D., \& Girault, J.A. (2006) Inhibition of ERK pathway or protein synthesis during reexposure to drugs of abuse erases previously learned place preference. Proc Natl Acad Sci USA, 103, 2932-2937.

Valjent, E., Bertran-Gonzalez, J., Aubier, B., Greengard, P., Hervé, D., \& Girault, J.A. (2010) Mechanisms of locomotor sensitization to drugs of abuse in a two-injection protocol. Neuropsychopharmacology, 35, 401-415.

Vanderschuren, L.J., Donné Schmidt, E., De Vries, T.J., Van Moorsel, C.A.P., Tilders, F.J.H., \& Schoffelmeer, A.N.M. (1999) A single exposure to amphetamine is sufficient to induce longterm behavioral, neuroendocrine, and neurochemical sensitization in rats. J. Neurosci., 19, 9579-9586.

Vanderschuren, L.J., De Vries, T.J., Wardeh, G., Hogenboom, F.A., Schoffelmeer, A.N. (2001) A single exposure to morphine induces long-lasting behavioural and neurochemical sensitization in rats. Eur. J. Neurosci., 14, 1533-1538.

Vezina P. (1996) D1 dopamine receptor activation is necessary for the induction of sensitization by amphetamine in the ventral tegmental area. J Neurosci, 16, 2411-2420.

Vezina P. (2004) Sensitization of midbrain dopamine neuron reactivityand the self-administration of psychomotor stimulant drugs. Neurosci. Biobehav. Rev, 27, 827-839. 
Weiss, S.R., Post, R.M., Pert, A., Woodward, R., Murman, D. (1989). Context-dependent cocaine sensitization: differential effect of haloperidol on development versus expression. Pharmacol Biochem. Behav., 34, 655-661.

Xu, M., Moratalla, R., Gold, L.H., Hiroi, N., Koob, G.F., Graybiel, A.M., \& Tonegawa, S. (1994) Dopamine D1 receptor mutant mice are deficient in striatal expression of dynorphin and in dopamine-mediated behavioral responses. Cell, 79, 729-742.

$\mathrm{Xu}, \mathrm{M}$., et al., (2000) Behavioral responses to cocaine and amphetamine administration in mice lacking the dopamine D1 receptor. Brain Res, 852, 198-207.

Yager, L.M., Garcia, A.F., Wunsch, A.M., \& Ferguson, S.M. (2015) The ins and outs of the striatum: role in drug addiction. Neuroscience, 301, 529-541.

Yan, Y., Newman, A.H. \& Xu, M. 2014 Dopamine D1 and D3 receptors mediate reconsolidation of cocaine memories in mouse models of drug self-administration. Neuroscience, 278, 154-164.

Zhang, J., Zhang, L., Jiao, H., Zhang, Q., Zhang, D., Lou, D., Katz, J.L., \& Xu, M. (2006) c-Fos facilitates the acquisition and extinction of cocaine-induced persistent changes. $J$ Neurosci, 26, 13287-13296. 


\section{Figure legends}

Figure 1. Experimental design of Gi-DREADD inhibition of D1 neurons in cocaine two-injection protocol of sensitization (TIPS). A) Gi-DREADD (hM4Di) expression in Drd1-expressing cells (D1-cells) of double transgenic Drd1-Cre x Gi-DREADD mice (referred to as D1-Gi-DREADD mice). Following Cre-mediated removal of an upstream floxed-STOP cassette, the HA-tagged Gi-DREADD-mCitrine mRNA is expressed in D1-cells. HA, hemagglutinin epitope tag, PTA, porcine teschovirus cleavage site. B) Groups of mutant and wild type mice used in the study. The number of mice and sex ratio is indicated for each group. C) Schematic schedule of behavioral experiments. Cocaine, $20 \mathrm{mg} / \mathrm{kg}$, clozapine, CLZ, $0.1 \mathrm{mg} / \mathrm{kg}$.

Figure 2. CLZ decreases cocaine-induced locomotor activity and Fos expression in Gi-DREADD-expressing striatal neurons. A) Schematic experimental design. Vehicle or CLZ was injected $30 \mathrm{~min}$ before cocaine administration. The locomotor activity box is a circular corridor. Mice were killed $90 \mathrm{~min}$ after cocaine administration for immunofluorescence. B) Inhibition of D1-neurons by stimulating Gi-DREADD with CLZ prevents cocaine-induced hyper-locomotion. Locomotor activity was measured during $60 \mathrm{~min}$ after cocaine injection in mice pretreated with vehicle or CLZ as indicted. Data were collected in 5-min bins and shown for each mouse. Bars indicate means + SEM, $\mathrm{n}=5$ mice per group. Mann-Whitney's $\mathrm{U}=0, \mathrm{p}=0.0079,{ }^{* *} \mathrm{p}<0.01$. C) Fosand HA-immunoreactivity $90 \mathrm{~min}$ after cocaine administration $\left(20 \mathrm{mg} \mathrm{kg}{ }^{-1}\right.$ i.p.) were visualized by immunofluorescence and confocal microscopy. Representative images of double immunolabeling of Fos (green) and HA (red) in NAc shell. Merged image demonstrates colocalization (arrows) of HA-Gi-DREADD and Fos. Scale bar, $50 \mu \mathrm{m}$. D) The position of the striatal regions used for quantification $(388 \times 388 \mu \mathrm{m})$ is indicated by red squares on a mouse brain coronal section at $0.98 \mathrm{~mm}$ antero-posterior coordinate (after Paxinos and Franklin, 2001): dorsomedial (DM) and dorsolateral (DL) striatum, NAc core (C) and shell (S). E) The percentage of Fos-positive neurons among HA-positive neurons was analyzed in the 4 regions indicated in D. Each data point corresponds to the mean results of the right and left side for each region in one mouse ( 5 mice per group), with bars indicating means + SEM. Mann-Whitney's test, NAc core, $U=26, p<0.075$, NAc shell, $U=18.5, p=0.016, D M, U=5, p=$ $210^{-4}, \mathrm{DL}, \mathrm{U}=18, \mathrm{p}=0.067 .{ }^{*} \mathrm{p}<0.05,{ }^{*} \mathrm{p}<0.01,{ }^{* * *} \mathrm{p}<0.001$.

Figure 3. Gi-DREADD-induced inhibition of D1-neurons decreases acute cocaine-induced hyper-locomotion and cocaine sensitization in the TIPS protocol. A-D) On day 0, D1-Gi-DREADD mice (D1-DREADD, groups 1-4) and wild type mice (WT, groups 5-8, independent experiments) were injected with vehicle (Veh, groups 1, 2, $5,6)$ or CLZ $(0.1 \mathrm{mg} / \mathrm{kg}$, groups $3,4,7,8)$ and placed in the locomotor activity box (circular corridor). Thirty min later, they were injected with saline (Sal, groups 1, 3, 5, 7) or cocaine (Coc, $20 \mathrm{mg} / \mathrm{kg}$, groups 2, 4, 6, 8). (A) Timecourse of locomotor activity measured in 5-min bins in D1-Gi-DREADD mice. Repeated measures 2-way ANOVA, interaction, $\mathrm{F}_{(33,407)}=3.25, \mathrm{p}<10^{-4}$, time, $\mathrm{F}_{(11,407)}=5.16$, $\mathrm{p}<10^{-4}$, groups, $\mathrm{F}_{(3,37)}=25.92, \mathrm{p}<10^{-4}$. (B) Basal locomotor activity during the $30 \mathrm{~min}$ before cocaine injection, in D1-Gi-DREADD and WT mice after vehicle or CLZ pretreatment as indicated. CLZ decreased basal locomotion in transgenic mice (pooled groups 1 and 2 vs pooled 
groups 3 and 4, Mann-Whitney test, $\mathrm{U}=21, \mathrm{p}<10^{-4}$ ) but not in WT mice (pooled groups 5 and 6 vs pooled groups 7 and 8, Mann-Whitney test, $\mathrm{U}=654, \mathrm{NS})$. C) Total locomotor activity during the $60 \mathrm{~min}$ after cocaine injection. D1-Gi-DREADD mice (groups 1-4), Kruskal-Wallis test value $=25.2, \mathrm{p}<10^{-4}$, Dunn's multiple comparisons test, 1 vs $2, \mathrm{p}<0.05$. Wild type mice (groups 5-8, independent experiment) Kruskal-Wallis test value $=50.8, \mathrm{p}<10^{-4}$, Dunn's multiple comparisons test, 5 vs 6 and 7 vs $8, p<10^{-4}$. D) Same data as in C) but shown separately for males (M) and females (F). E-F) On day 10, all mice were injected with vehicle, put in the locomotor activity box and injected with cocaine $(20 \mathrm{mg} / \mathrm{kg}) 30 \mathrm{~min}$ later. E) Time-course of locomotor activity measured in 5-min bins in D1-GiDREADD mice. Repeated measures 2-way ANOVA, interaction, $\mathrm{F}_{(33,407)}=1.93, \mathrm{p}=0.002$, time, $\mathrm{F}_{(11,407)}=17.21$, $\mathrm{p}<10^{-4}$, groups, $\mathrm{F}_{(3,37)}=7.29, \mathrm{p}=610^{-4}$. F) Total locomotor activity during the $60 \mathrm{~min}$ after cocaine injection. D1Gi-DREADD mice (groups 1-4), 2-way ANOVA, interaction, $\mathrm{F}_{(1,37)}=5.93, \mathrm{p}=0.02$, pretreatment on day $0, \mathrm{~F}_{(1,37)}$ $=2.06$, NS, treatment on day $0, F_{(1,37)}=13.62, p=710^{-4}$, Sidak's multiple comparisons test, 1 vs $2, p<0.001$, WT mice (groups 5-8, independent experiment), 2-way ANOVA, interaction, $F_{(1,75)}=0.24$, NS, pretreatment on day 0 , $\mathrm{F}_{(1,75)}=1.83$, NS, treatment on day $0, \mathrm{~F}_{(1,75)}=16.92$, $\mathrm{p}<10^{-4}$, Sidak's multiple comparisons test, $5 \mathrm{vs} 6, \mathrm{p}<0.05,7$ vs $8, \mathrm{p}<0.01$. In $\mathrm{A}$ and $\mathrm{E}$ each point correspond to a group mean $\pm \mathrm{SEM}$. In $\mathrm{B}, \mathrm{C}, \mathrm{D}$, and $\mathrm{F}$, each point correspond to a mouse, bars indicate means + SEM. NS, not significant, ${ }^{*} \mathrm{p}<0.05,{ }^{* *} \mathrm{p}<0.01,{ }^{* * *} \mathrm{p}<0.001,{ }^{* * * *} \mathrm{p}<10^{-4}$.

Figure 4. Gi-DREADD-induced inhibition of D1-neurons blocks cocaine-induced locomotion in previously sensitized mice without persistent effect on its further expression. A-C) On day 11, the same D1-Gi-DREADD and WT mice as in Fig. 3 were all injected with CLZ, placed in the locomotor activity box, and 30 min later, injected with cocaine $(20 \mathrm{mg} / \mathrm{kg})$. The time-course of locomotor activity was measured in 5-min bins. A) D1-Gi-DREADD mice, repeated measures 2-way ANOVA, interaction, $\mathrm{F}_{(33,407)}=1.39$, NS, time, $\mathrm{F}_{(11,407)}=7.29$, $\mathrm{p}<10^{-4}$, groups, $\mathrm{F}_{(3 \text {, }}$ ${ }_{37}=1.20$, NS. B) Total locomotor activity during the $60 \mathrm{~min}$ after cocaine injection. D1-Gi-DREADD mice (groups $1-4$ ), Kruskal-Wallis test value $=4.6$, NS. WT mice (groups 5-8, independent experiment), Kruskal-Wallis test value $=6.25$, NS. C) Pairwise comparison for each mouse of locomotor responses to cocaine on day 10 without CLZ pretreatment (data from Fig. 3E) and on day 11 with CLZ (data from Fig. 4B). Paired t-test, group 1, p =0.001, group 3, $p=0.001$, group $4, p=0.038$. Wilcoxon matched-pairs test, group $2, p=0.001$. D-F) On day 12 , the same mice as in A were all injected with vehicle, placed in the locomotor activity box, and 30 min later, injected with cocaine $(20 \mathrm{mg} / \mathrm{kg})$. The time-course of locomotor activity was measured in 5-min bins. D) D1-Gi-DREADD mice, repeated measures 2-way ANOVA, interaction, $\mathrm{F}_{(33,397)}=1.41$, NS, time, $\mathrm{F}_{(11,396)}=36.87, \mathrm{p}<10^{-4}$, groups, $\mathrm{F}_{(3,36)}=$ 0.63 , NS. E) Total locomotor activity during the $60 \mathrm{~min}$ after cocaine injection. D1-Gi-DREADD mice (groups 14), Kruskal-Wallis test value $=2.39$, NS. Wild type mice (groups 5-8, independent experiment) Kruskal-Wallis test value $=0.76$, NS. F) Pairwise comparison for each mouse of locomotor responses to cocaine on day 10 without CLZ pretreatment (data from Fig. 3B) and on day 12 (data from Fig. 4E). Paired t-test, group 1, p = 0.009, group 2, $\mathrm{p}=0.235$, group $3, \mathrm{p}=0.001$. Wilcoxon matched-pairs test, group $4, \mathrm{p}=0.014$. In $\mathrm{A}$ and $\mathrm{D}$, each point correspond to a group mean \pm SEM. In $\mathrm{B}, \mathrm{C}, \mathrm{E}$, and $\mathrm{F}$, each point correspond to a mouse. In $\mathrm{B}$ and $\mathrm{E}$, bars indicate means + SEM. NS, not significant, ${ }^{*} \mathrm{p}<0.05, * * \mathrm{p}<0.01, * * * \mathrm{p}<0.001$. 
Fig 1

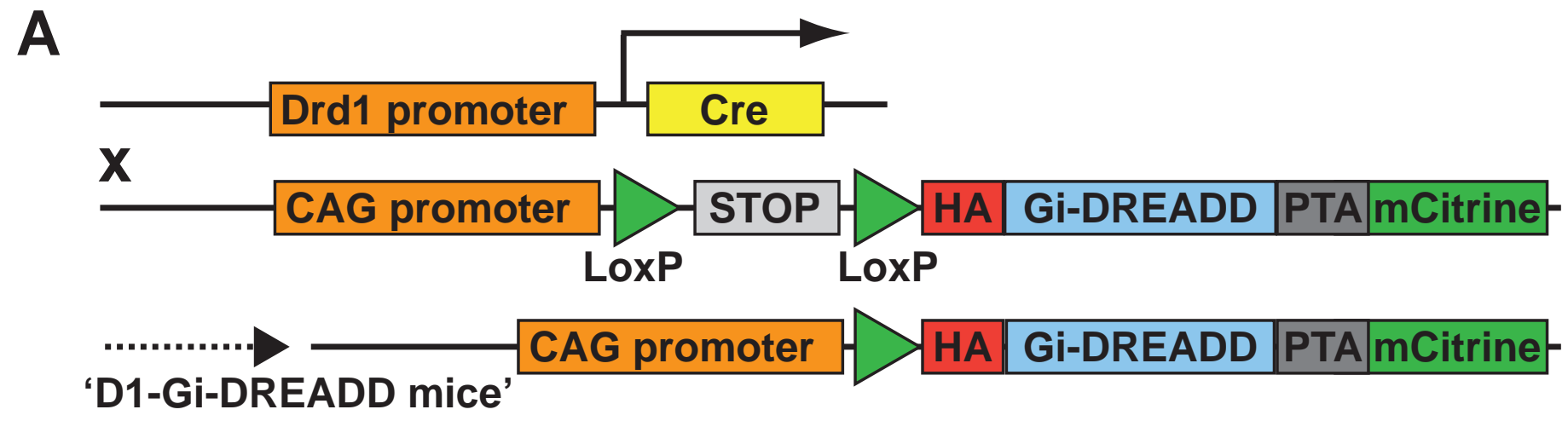

\begin{tabular}{|c|c|c|c|c|c|}
\hline Group & Mouse line & Day 0 & Day 10 & Day 11 & Day 12 \\
\hline Group $1(n=8, M / F=5 / 3)$ & \multirow{4}{*}{ D1-Gi-DREADD } & Vehicle + Saline & \multirow{8}{*}{$\begin{array}{c}\text { Vehicle } \\
+ \\
\text { Cocaine }\end{array}$} & \multirow{8}{*}{$\begin{array}{c}\text { CLZ } \\
+ \\
\text { Cocaine }\end{array}$} & \multirow{8}{*}{$\begin{array}{c}\text { Vehicle } \\
+ \\
\text { Cocaine }\end{array}$} \\
\hline Group $2(n=11, M / F=6 / 5)$ & & Vehicle + Cocaine & & & \\
\hline Group $3(n=11, M / F=6 / 5)$ & & CLZ + Saline & & & \\
\hline Group $4(n=11, M / F=6 / 5)$ & & CLZ + Cocaine & & & \\
\hline Group $5(n=20, M / F=10 / 10)$ & \multirow{4}{*}{ Wild type } & Vehicle + Saline & & & \\
\hline Group $6(n=20, M / F=11 / 9)$ & & Vehicle + Cocaine & & & \\
\hline Group $7(n=19, M / F=10 / 9$ & & CLZ + Saline & & & \\
\hline Group $8(n=20, M / F=10 / 10)$ & & CLZ + Cocaine & & & \\
\hline
\end{tabular}

CLZ $0.1 \mathrm{mg} \mathrm{kg}^{-1}$ i.p. Cocaine $20 \mathrm{mg}^{-1} \mathrm{~kg}$ i.p.

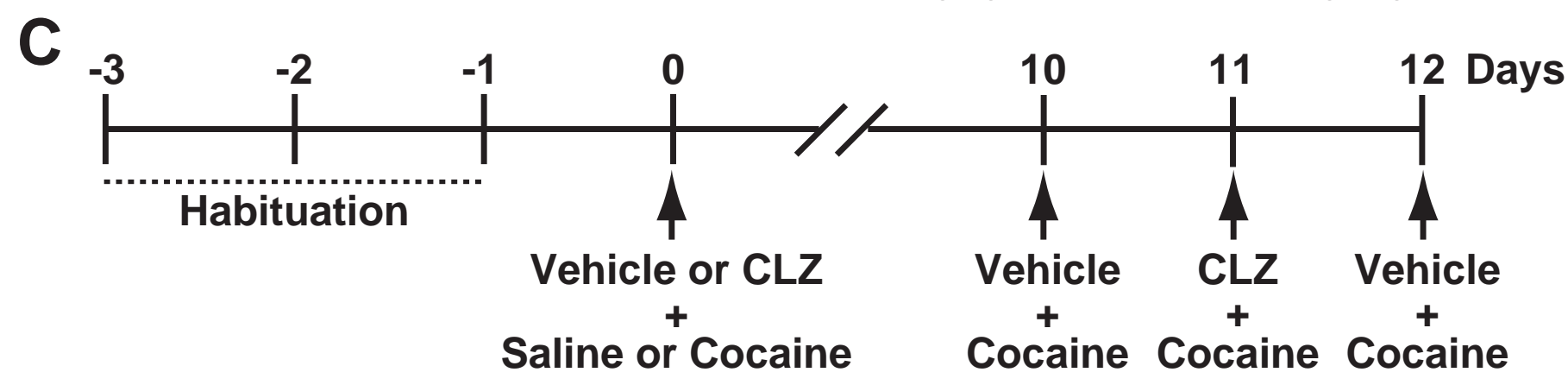




\section{Fig 2}

A

Locomotor activity box

D1-Gi-DREADD mice

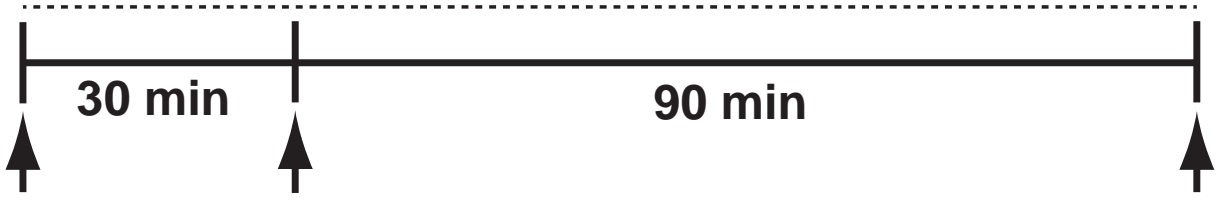

Group A $(n=5, M / F=4 / 1)$ Vehicle Cocaine $20 \mathrm{mg} \mathrm{kg}^{-1}$

Brain

Group B ( $n=5, M / F=3 / 2) \quad C L Z 0.1 \mathrm{mg} \mathrm{kg}^{-1}$
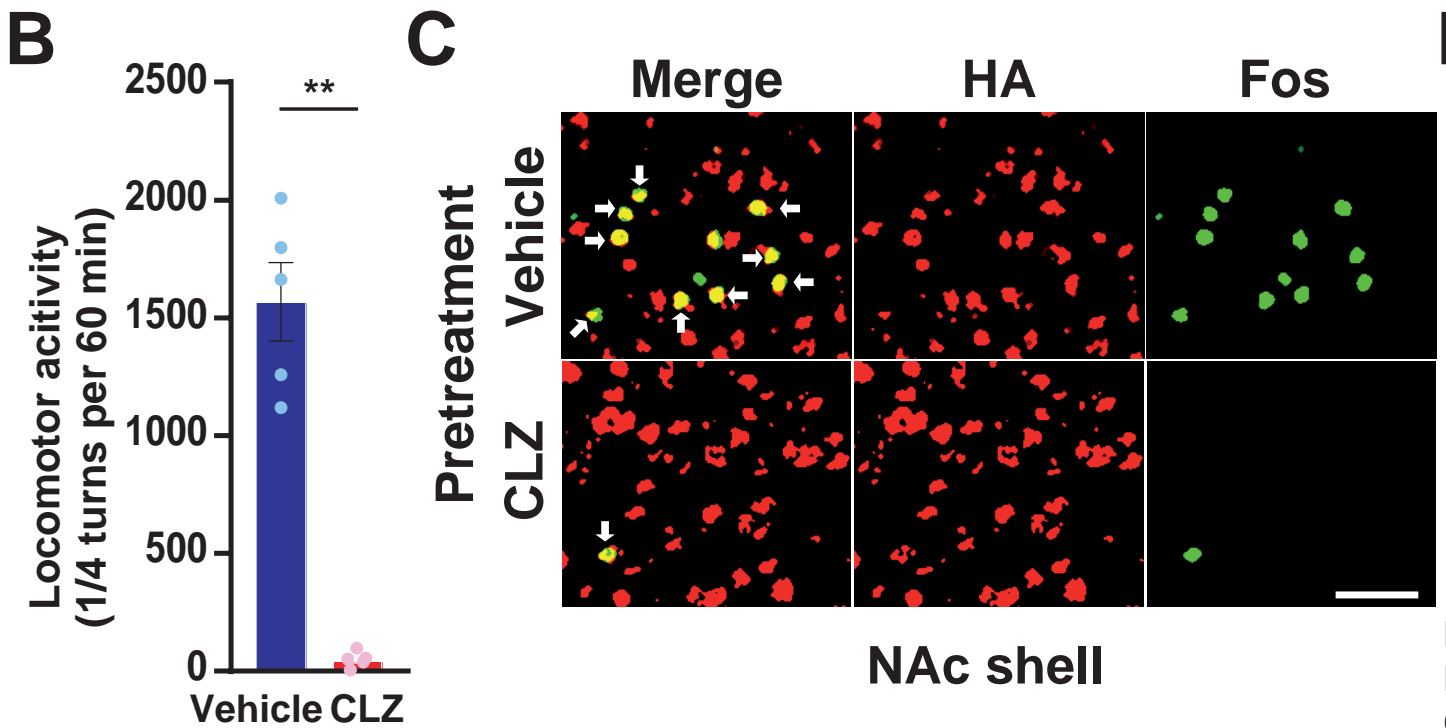

D

NAc shell

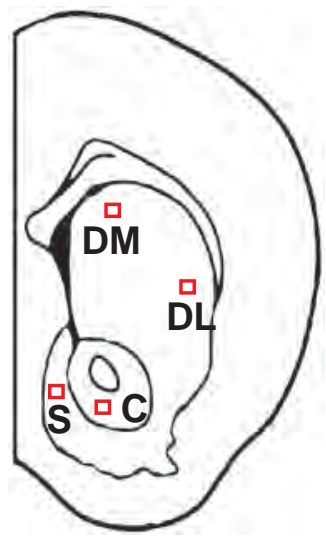

DM, dorso-medial striatum DL, dorso-lateral striatum C, NAc core S, NAc shell

E

NAc core

NAc shell

DM

DL
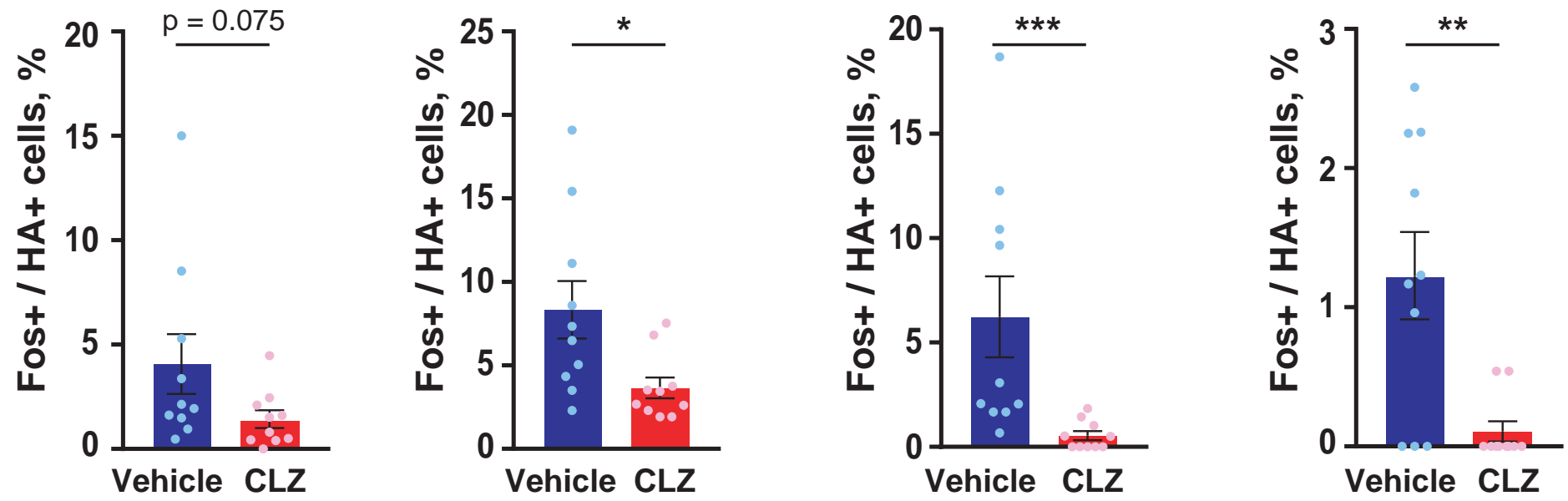


\section{Fig 3}

A Day 0

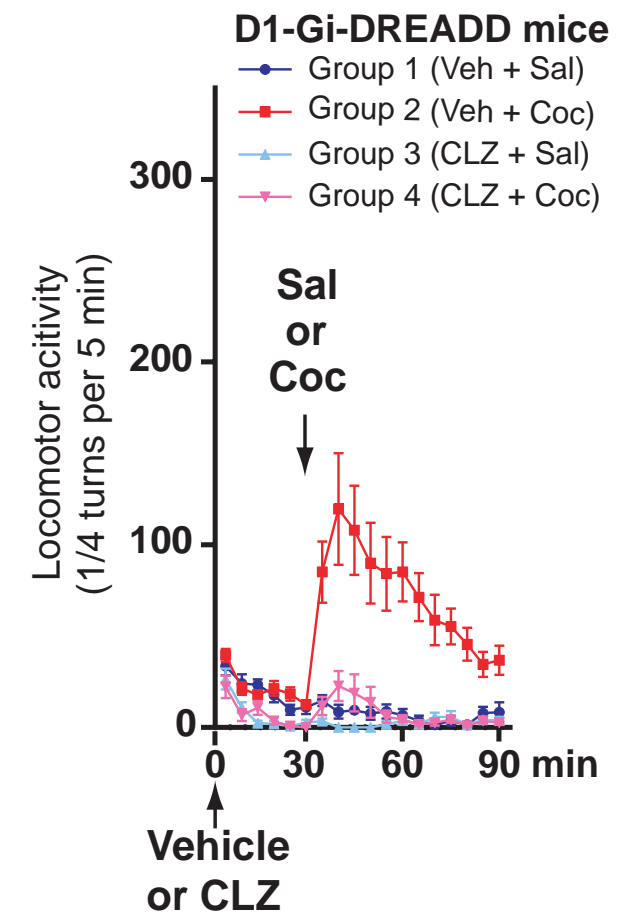

D Day 0 (30-90 min)

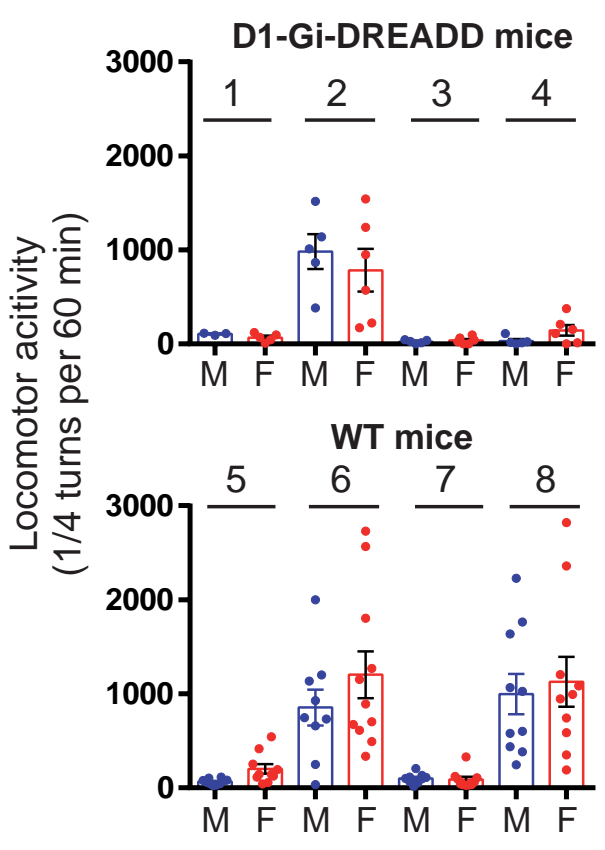

B
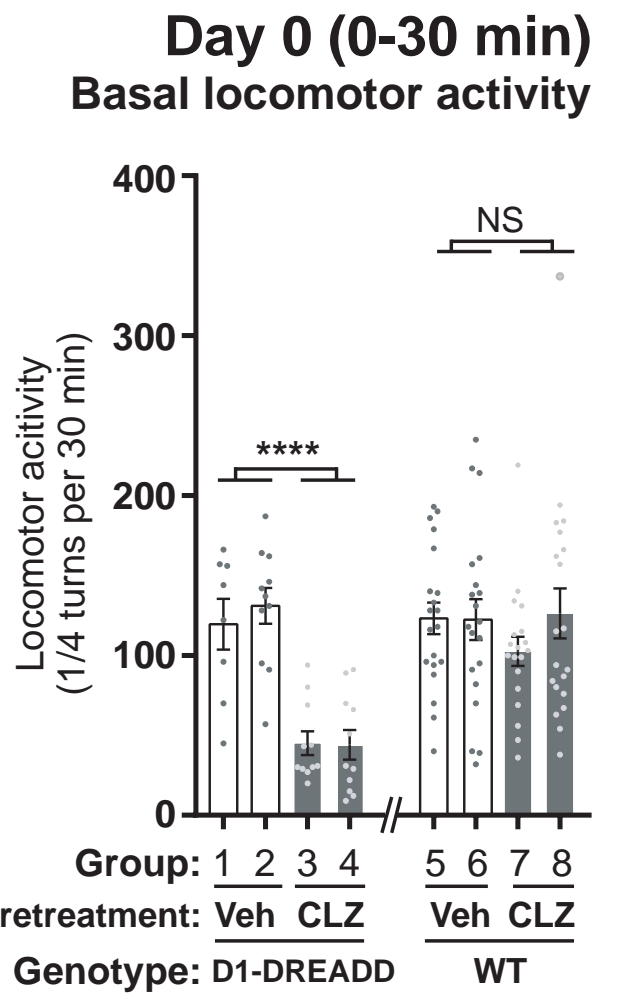

E Day 10

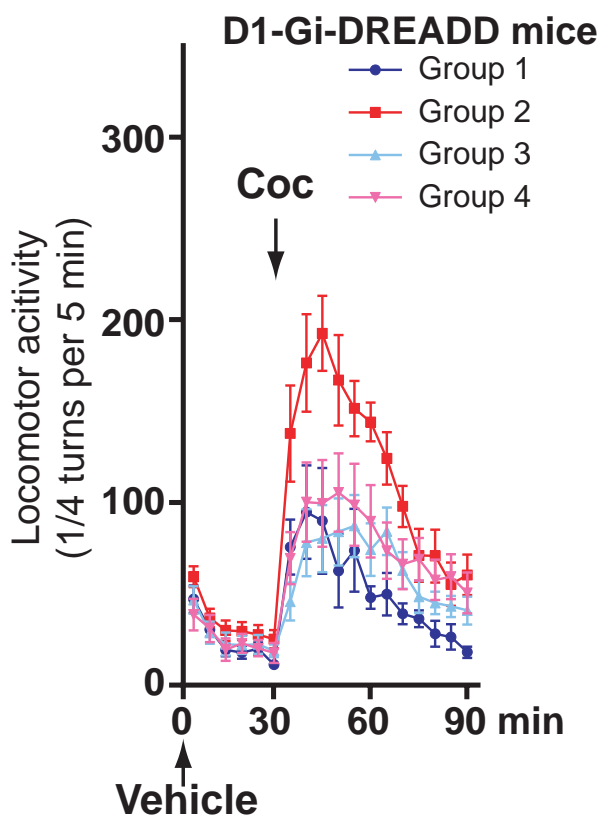

C Day 0 (30-90 min) Cocaine-induced activity

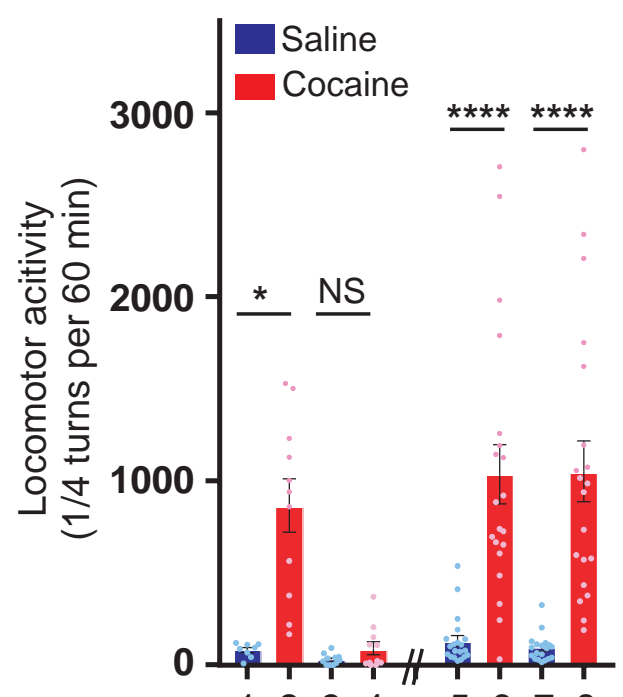

Group: $1234 \quad 5678$ Pretreatment: Veh CLZ Veh CLZ Genotype: $\overline{\text { D1-DREADD }}$ WT

F Day 10 (30-90 min) Veh + Coc

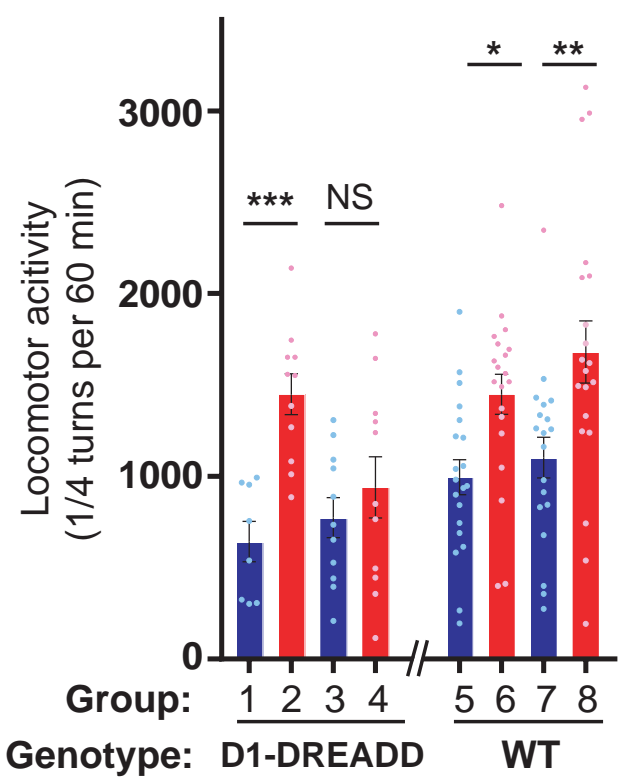


